\title{
The effect of structural characteristics on electrical and physical properties of electrically conductive compositions based on mineral binders
}

\author{
Oleksiy Pluhin ${ }^{1}$, Andrii Plugin ${ }^{2}$, Dmytro Plugin ${ }^{2, *}$, Olga Borziak $^{2}$, and Oleksiy Dudin ${ }^{3}$ \\ ${ }^{1}$ Ukrainian State University of Railway Transport, Structural Mechanics and Hydraulics Departmen, \\ Feuerbach sq. 7, 61050 Kharkiv, Ukraine \\ ${ }^{2}$ Ukrainian State University of Railway Transport, Building Materials and Structures Department, \\ Feuerbach sq. 7, 61050 Kharkiv, Ukraine \\ ${ }^{3}$ Ukrainian State University of Railway Transport, Track and Track Sector Department, Feuerbach sq. \\ 7, 61050 Kharkiv, Ukraine
}

\begin{abstract}
The present-day situation is such that industrial production, municipal economy, traffic, etc consume a continuously increasing amount of energy. As a result, the range of propagation of electric stray currents, including their appropriate potentials and leakage currents that affect building structures and facilities is expanded and this is of importance. It requires stricter demands regarding protection of building structures and facilities exposed to electric currents and potentials. This study gives the research data on the influence of structure on electrophysical properties, in particular specific electric resistance of the silicate compositions obtained for electrocorrosion protection. The theoretical research done allowed us to plot the relationships to define the specific electric resistance and the specific conductivity of a composite material using the data on its composition and the specific electric resistance of the filler and matrix. The algorithm to define the specific electric resistance of the composite material was developed for research and/or technological purposes by using the data on specific electric resistance of the filler, matrix and composition.
\end{abstract}

\section{Introduction}

Special requirements are set to the specific electric resistance and/or specific electric conductivity of electrical concretes and mortars that are considered to be special materials. It has nothing to do with high or low requirements; they are limited by a narrow range of values. Heavy-weight concretes of rail constructions and rail supports have an increased electric resistance $[1,2]$ to provide the electrocorrosion protection and reliable operation of rail chains. The authors of this research paper developed the National Standard DSTU B V.2.6-2009:2016 "Preliminary Stressed Reinforced Concrete Railway Ties for the

\footnotetext{
${ }^{*}$ Corresponding author: plugin.da@gmail.com
} 
Railroads of the 1520 and 1435-mm Tracks. Technical Specifications" to provide the electrocorrosion protection by normalization of specific electric resistance of the concrete making it equal to at least $110 \mathrm{Ohm} \cdot \mathrm{m}$ (for a certain humidity). An increased electrical resistance is also required to provide the electrocorrosion protection during the structure repair, using for this purpose the polymer-cement slurry [3]. Electroconductive concretes are used for heating elements [4-6] and the ionizing radiation protection [7]. The electric conductivity of concrete is controlled with electroconductive fillers. These are usually carbon-graphite [5,6] and metal containing [7] fillers. The composition (the component ratio) $[8]$ and the composite structure $[9,10]$, especially the microstructure of it $[7,10,11]$ also affect the electrical conduction, including technological impacts that arise during the composite production $[8,12,13]$. The electric conductivity of concrete greatly depends on humidity [14] that can create problems for operation of special structures. The empiric method is used for the control of electric conductivity in composite material production; its dependence on receptor-process factors is experimentally studied. This is a rather laborious and time-consuming approach. Therefore, the problem of prediction of specific electric resistance of the composite material using the data on electric resistance of filler and matrix and the summarized characteristics of its composition is rather vital.

The objective of the research was to develop the algorithm for the prediction of specific electric resistance of the composite material using the data on specific electric resistance of its components and summarized characteristics of its composition.

\section{Research Methods and Materials}

This is a theoretical investigation. Based on the review of reference data, the physical (three-dimensional geometric) model of the structure of composite material was developed and it was converted into the mathematical model, using the computation method. The mathematical model served as the basis for the development of an algorithm to predict the specific electric resistance of the composite material on the basis of data on the specific electric resistance of filler, matrix and composition.

The model and the algorithm were developed for composite materials whose specific electric conductivity and resistance should meet special requirements ranging from electroconductive to electric insulating properties. The matrix of these materials is represented by hardened cementing materials, for example Portland cement stone, solidified liquid glass, etc. Fillers with high electric conductivity are graphite powder, ground coke, metal powders, etc. Fillers with high electric resistance are quartz, granite, etc. To realize the algorithm we need to have reference or experimental data on specific electric conductivity and/or specific electric resistance of matrix and filler.

\section{Research data}

To provide the electrocorrosion protection we will study the influence of the structure on electrophysical properties, in particular, specific electric resistance of silicate compositions. The composite material (the matrix composite [15]) consists of structure-forming particles (filler) connected together by the matrix. To study and describe quantitative mechanisms in [16] the structure is conditionally represented by the spatial geometric model with the regular distribution of ball-shaped structure forming particles of the same diameter. Fig. 1a gives the diagram of the structure of such a composition and Fig. 1b gives the diagram of its conditional spatial elementary cell, which consists of one particle of the filler of the average size (diameter) $d$, $\mathrm{m}$, surrounded at the three sides (in space) by the matrix of an average thickness in places of a maximum proximity of the filler particles $\delta, \mathrm{m}$, Fig. $1 \mathrm{~b}$. 


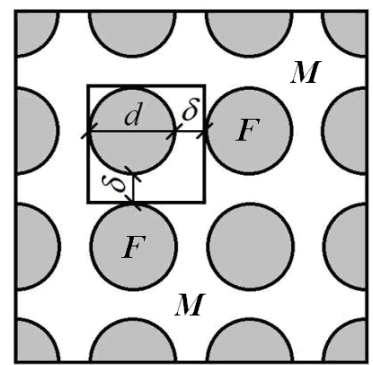

(a)

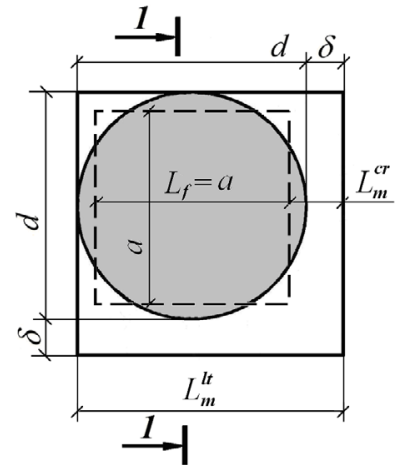

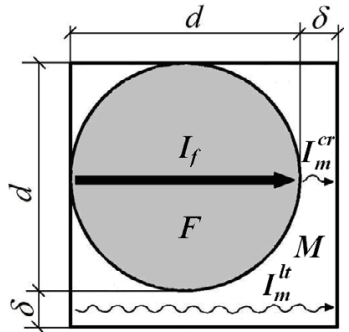

(b)

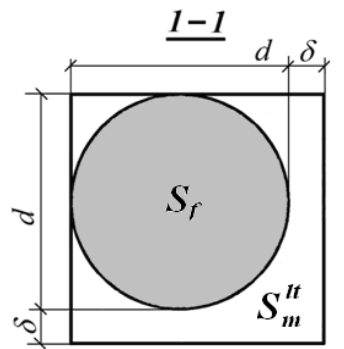

(c)

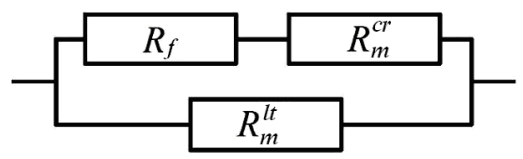

(d)

Fig. 1. The diagram of formation of the electric resistance of composite material: (a) composite material structure diagram; (b) the diagram of conditional elementary cell of the composite material and the current flowing through it; (c) the equivalent circuit of conditional elementary cell of the composite material and the electric current flowing through it; (d) the equivalent circuit of electric resistance of the elementary cell of composite material; $(\mathrm{F})$ is the filler and $(\mathrm{M})$ is the matrix.

Fig. 1d gives the equivalent circuit of the conditional elementary cell of composite material and the electric current flowing through it. Fig. 1b, c, shows that the total electric current $I$ that flows through the conventional elementary cell is subdivided into the currents that flow through the filler particle $\left(I_{f}\right)$ and the interlayers between the filler particles in transverse and longitudinal directions $\left(I_{m}{ }^{l t}\right)$ of the current flow. Since the length of the filler particle is a variable value that varies in the range of $0-d$ the length of the transverse section of the matrix is also a variable value that varies in the range $\delta-\delta+d / 2$, then we will conditionally change the form of the ball-shaped filler particle given in the diagram in Fig. 1a to the cube of the same volume (Fig. 1c):

$$
V_{\text {ball }}=\frac{\pi d^{3}}{6}=V_{\text {cube }}=a^{3}
$$

The length of the cube edge is equal to:

$$
\frac{\pi d^{3}}{6}=a^{3}, a=d \sqrt[3]{\frac{\pi}{6}}
$$


According to the diagrams given in Fig. 1b, c the specific electric resistance of the composite material is equal to the specific electric resistance of its conditional elementary cell:

$$
\rho_{c}=\frac{R S}{L},
$$

where $R$ is the electric resistance, Ohm; $S$ is the cross-section area, $\mathrm{m}^{2} ; L$ is the length, $\mathrm{m}$.

$$
S=(d+\delta)^{2} ; L=d+\delta .
$$

Proceeding from such a current flow diagram, the equivalent circuit of the electric resistance of conditional elementary cell of the composite material can be presented in the form given in Fig. 1d by analogy with [14], where the electric supports (conductors) of the filler $R_{f}$ and the matrix interlayer have tandem connection in the transverse direction of the current flow $R_{m}{ }^{c r}$ and the electric resistance of matrix interlayer in the longitudinal direction of the current flow $R_{m}{ }^{l t}$ is connected in parallel to the first two $\left(R_{f}\right.$ and $\left.R_{m}{ }^{c r}\right)$.

According to the diagram in Fig. $1 \mathrm{c}$, $\mathrm{d}$ the electric conductivity $1 / R_{c}$ (an inverse value of the electric resistance $R_{c}$ ) of conditional elementary cell of the composite material will be equal to:

$$
\frac{1}{R_{c}}=\frac{1}{R_{f}+R_{m}^{c r}}+\frac{1}{R_{m}^{l t}},
$$

where $R_{f}$ is the electric resistance of a filler particle, Ohm; $R_{m}{ }^{c r} ; R_{m}{ }^{l t}$ are the electric resistances of matrix interlayers in the transverse and longitudinal directions of the current flow, respectively, Ohm:

$$
\begin{gathered}
R_{f}=\frac{\rho_{f} L_{f}}{S_{f}}=\frac{\rho_{f} d \sqrt[3]{\frac{\pi}{6}}}{d^{2} \sqrt[3]{\left(\frac{\pi}{6}\right)^{2}}}=\frac{\rho_{f} \sqrt{\frac{6}{\pi}}}{d}=\frac{\rho_{f} \cdot 1.38}{d} \\
R_{m}^{c r}=\frac{\rho_{m} L_{m}^{c r}}{S_{f}}=\frac{\rho_{m} \cdot d\left(1-\sqrt[3]{\frac{\pi}{6}}\right)+\delta}{d^{2} \sqrt[3]{\left(\frac{\pi}{6}\right)^{2}}}=\frac{2 \delta}{\pi d^{2}}+\frac{2 \rho_{m}}{\pi d}-\frac{\rho_{m} \sqrt{\frac{6}{\pi}}}{d}=\frac{2 \delta}{\pi d^{2}}+\frac{2 \rho_{m}}{\pi d}-\frac{\rho_{m} \cdot 1.38}{d} \\
R_{m}^{l t}=\frac{\rho_{m} L_{m}^{l t}}{S_{m}^{l t}}=\frac{\rho_{m}(d+\delta)}{(d+\delta)^{2}-d^{2} \sqrt[3]{\left(\frac{\pi}{6}\right)^{2}}}=\frac{\rho_{m} d+\delta}{(d+\delta)^{2}-\frac{\pi d^{2}}{2}}=\frac{\rho_{m} d+\delta}{(d+\delta)^{2}-1.57 d^{2}}
\end{gathered}
$$

where $L_{f}$ is the length of a filler particle, which is equal to the cube of the edge length $a, \mathrm{~m}$;

$$
L_{f}=a=d \sqrt[3]{\frac{\pi}{6}}
$$


$L_{m}{ }^{c r}$ is the size of a matrix interlayer in the transverse direction of the current flow, which is equal to the thickness of it $\delta, \mathrm{m}$;

$$
L_{m}^{c r}=(d+\delta)-a=d+\delta-d \sqrt[3]{\frac{\pi}{6}}=d\left(1-\sqrt[3]{\frac{\pi}{6}}\right)+\delta
$$

$L_{m}{ }^{l t}$ is the size of a matrix interlayer in the longitudinal direction of the current flow, which is equal to $(d+\delta), \mathrm{m} ; S_{f}$ is the cross-section area of a filler particle, $\mathrm{m}^{2} ; S_{m}{ }^{c r}, S_{m}{ }^{l t}$ are the cross-section areas of matrix interlayers for the transverse and longitudinal directions of the current flow, respectively $\mathrm{m}^{2}$ :

$$
S_{f}=S_{m}^{c r}=a^{2}=\left(d \sqrt[3]{\frac{\pi}{6}}\right)^{2}=d^{2} \sqrt[3]{\left(\frac{\pi}{6}\right)^{2}} ; S_{m}^{l t}=S-S_{f}=(d+\delta)^{2}-d^{2} \sqrt[3]{\left(\frac{\pi}{6}\right)^{2}}
$$

By substituting $(3 ; 4 ; 6 ; 7 ; 8)$ into $(5)$ we obtain the equations to determine the specific electric conductivity for the composition $1 / \rho_{c}$, the inverse value of its specific electric resistance $\rho_{c}$ :

$$
\begin{aligned}
\frac{1}{\rho_{c}(d+\delta)}= & \frac{1}{\frac{\rho_{f} \sqrt{\pi / 6}}{d}+\frac{2 \delta}{\pi d^{2}}+\frac{2 \rho_{m}}{\pi d}-\frac{\rho_{m} \sqrt{\pi / 6}}{d}+\frac{1}{\frac{\rho_{m} d+\delta}{(d+\delta)^{2}-\pi d^{2} / 2}}=} \\
= & \frac{d+\pi d^{2}+\pi d-d}{\rho_{f} \sqrt{\frac{\pi}{6}}+2 \delta+2 \rho_{m}-\rho_{m} \sqrt{\frac{\pi}{6}}}+\frac{(d+\delta)^{2}-\frac{\pi d^{2}}{2}}{\rho_{m}(d+\delta)}= \\
& =\frac{\pi d^{2}+\pi d}{0.72 \rho_{f}+2 \delta+1.28 \rho_{m}}+\frac{(d+\delta)^{2}-1.57 d^{2}}{\rho_{m}(d+\delta)} ; \\
\frac{1}{\rho_{c}} & =\frac{\pi d^{2}+\pi d \cdot(d+\delta)}{0.72 \rho_{f}+2 \delta+1.28 \rho_{m}}+\frac{(d+\delta)^{2}-1.57 d^{2}}{\rho_{m}} .
\end{aligned}
$$

We can see that the specific electric conductivity of the composition $1 / \rho_{c}$ and its specific electric resistance depend on the specific electric resistance of the filler $\rho_{f}$ and the matrix $\rho_{m}$ and such characteristics of the composition structure as $d, \delta$ and their ratio $\delta / d$. We will study the influence of the composition of composite material on the structure characteristics.

By analogy with $[16,17]$ we will use for this purpose the structural characteristic of the composite material, in particular a factor of separation of the filler by the matrix $\eta$. Using the approach described in [18] we obtain the formula for the separation factor $\eta$. Let us assume that the spatial model of the composite material given in Fig. 1a is formed by ballshaped filler particles separated by the matrix with regard to the initial state. In their initial state, the balls or spheres have a contact type arrangement and a simple cubic packing (Fig. 2a). In comparison to other dense packing (Fig. 2) the simple cubic packing is less dense [19]. Nevertheless, many researchers believe [20; 21] that the concrete structure and the structure of analogous composite materials correspond to a great extent to it. In the separated state, the order of relative position of spheres is retained. 
It was assumed earlier that the simplest regular element of the packing that corresponds to the conditional spatial elementary cell of the structure is the cube with the sphere inscribed into it. The cube side is equal to the sphere diameter (Fig. 3a). In this case the volume of voids $V_{v}$ is equal to the difference between the cube volume and the sphere volume:

$$
V_{v}=d^{3}-\frac{\pi d^{3}}{6}=\left(1-\frac{\pi}{6}\right) d^{3} .
$$

The hollowness of this packing of filler particles, in particular the spheres is equal to:

$$
E_{f}=\frac{\left(1-\frac{\pi}{6}\right) d^{3}}{d^{3}}=1-\frac{\pi}{6}=0.4764 .
$$

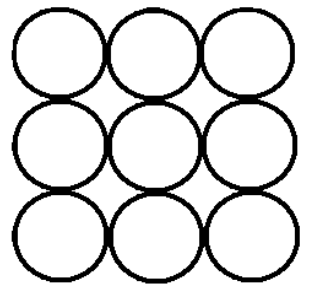

(a)

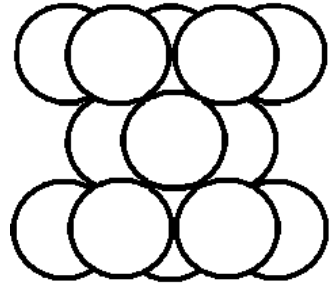

(b)

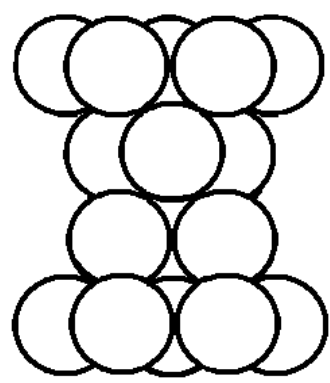

(c)

Fig. 2. Diagrams of the packing of the spheres of the same diameter, (a) the simple cubic packing; (b) the densest face-centered cubic packing; (c) the densest hexagonal packing.

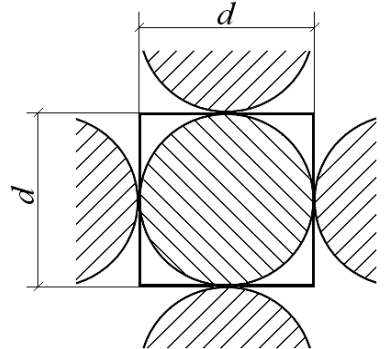

(a)

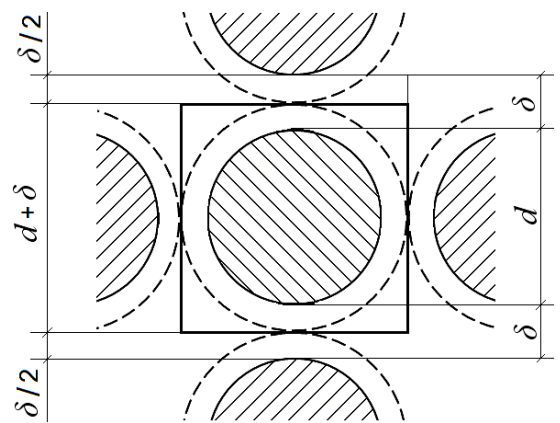

(b)

Fig. 3. The diagram of conditional elementary cell of the structure of composite material that corresponds to a simple cubic packing of the spheres: (a) without separation, (b) with separation.

In the case of contact-type arrangement of the spheres the matrix volume is equal to the volume of voids. The separation of the spheres by the matrix results in the formation of an interlayer between them with the thickness $\delta$ (Fig. 3b) and the matrix volume consists of the volume of voids between the spheres with the diameter $(d+\delta)$ and the difference in the volumes of spheres with diameters $(d+\delta)$ and $d$ :

$$
V_{m}=\left(1-\frac{\pi}{6}\right)(d+\delta)^{3}+\left[\frac{\pi}{6}(d+\delta)^{3}-\frac{\pi}{6} d^{3}\right]=(d+\delta)^{3}-\frac{\pi}{6} d^{3}
$$


The factor of separation of filler particles by the matrix $\eta$ is the ratio of the matrix volume $V_{m}$ and the volume of voids $V_{v}$ between the filler particles in the initial state for their contact arrangement without the separation:

$$
\eta=\frac{V_{m}}{V_{v}}=\frac{(d+\delta)^{3}-\frac{\pi}{6} d^{3}}{\left(1-\frac{\pi}{6}\right) d^{3}}=2.10\left(1+\frac{\delta}{d}\right)^{3}-1.10
$$

The derived equation corresponds to the analogous formula in [17].

If denser packing is formed each sphere occupies lesser total volume of the system in comparison with the simple cubic packing. Let us assume that a portion of the cube volume is equal to $k$. In this case the volume of voids $V_{v}$ and the hollowness $E_{f}$ will be equal to:

$$
\begin{aligned}
& V_{v}=k d^{3}-\frac{\pi d^{3}}{6}=\left(k-\frac{\pi}{6}\right) d^{3} . \\
& E_{f}=\frac{\left(k-\frac{\pi}{6}\right) d^{3}}{k d^{3}}=1-\frac{\pi}{6 k} .
\end{aligned}
$$

The value $k$ can be expressed via the hollowness by transforming (18):

$$
k=\frac{\pi}{6\left(1-E_{f}\right)}
$$

If the particles are drawn apart at the distance $\delta$, the matrix volume and the separation factor are equal, respectively, to

$$
\begin{gathered}
V_{m}=\left(k-\frac{\pi}{6}\right)(d+\delta)^{3}+\left[\frac{\pi}{6}(d+\delta)^{3}-\frac{\pi}{6} d^{3}\right]=k(d+\delta)^{3}-\frac{\pi}{6} d^{3} . \\
\eta=\frac{k(d+\delta)^{3}-\frac{\pi}{6}}{\left(1-\frac{\pi}{6}\right) d^{3}}=\frac{k}{k-\frac{\pi}{6}}\left(1+\frac{\delta}{d}\right)^{3}-\frac{\frac{\pi}{6}}{k-\frac{\pi}{6}} .
\end{gathered}
$$

By substituting (19) into (21) we obtain

$$
\eta=\frac{1}{E_{f}}\left(1+\frac{\delta}{d}\right)^{3}-\frac{1}{E_{f}}+1 .
$$
(22):

The relationship $\delta$ as a function of $d, E_{f}$ and $\eta$ will be obtained by properly transforming

$$
\delta=d\left[\sqrt[3]{E_{f}((\eta-1)+1)}-1\right]
$$

for the calcium silicate and sodium silicate-based composition: 


$$
\eta=\frac{V_{m}}{V_{v}}=\frac{\frac{S l}{\rho_{s l}}+\frac{L G}{\rho_{\mathrm{lg}}}+\frac{F S}{\rho_{f s}}}{\frac{F}{\rho_{f}^{a}} E_{f}}=\frac{\frac{S l}{L G} \times \frac{1}{\rho_{s l}}+\frac{1}{\rho_{\mathrm{lg}}}+\frac{F S}{L G} \times \frac{1}{\rho_{f s}}}{\frac{F}{L G} \times \frac{E_{f}}{\rho_{f}^{a}}},
$$

where $S l, L G, F S, F$ are the consumption of cinder, liquid glass, silicon fluoride, sodium and filler, $\mathrm{kg} / 1 \mathrm{~m}^{3}$ of the composition, respectively; $E_{f}=1-\rho_{f}^{a} / \rho_{f}$ is the hollowness of the package of filler particles in the compacted state (analogous to the hollowness of concrete fillers); $\rho_{s l}$, $\rho_{l g}, \rho_{f s}, \rho_{f}$ are the true hollowness of cinder, silicon fluoride, sodium and filler, $\mathrm{kg} / \mathrm{m}^{3}$, respectively; $\rho_{f}^{a}$ is the average filler density in the compacted state (analogous to the bulk density of concrete fillers) $\mathrm{kg} / \mathrm{m}^{3} ; S l / L G, F S / L G, F / L G$ are the quantitative mass relationship of appropriate composition components;

for Portland cement-based compositions:

$$
\eta=\frac{V_{m}}{V_{v}}=\frac{\frac{S}{\rho_{s}}+\frac{C}{\rho_{c}}+\frac{W}{\rho_{w}}}{\frac{F}{\rho_{f}^{a}} E_{f}}=\frac{\frac{S}{C} \times \frac{1}{\rho_{s}}+\frac{1}{\rho_{c}}+\frac{W}{C} \times \frac{1}{\rho_{w}}}{\frac{F}{C} \times \frac{E_{f}}{\rho_{f}^{a}}},
$$

where $S, C, W, F$ are the consumption of the sand, cement, water and the filler, $\mathrm{kg} / 1 \mathrm{~m}^{3}$ of the composition, respectively; $E_{f}=1-\rho_{f}^{a} / \rho_{f}$ is the hollowness of the packing of filler particles in the compacted state (analogous to the hollowness of concrete fillers); $\rho_{s}, \rho_{c}, \rho_{w}, \rho_{f}$ are the true densities of the sand, cement, water and filler, $\mathrm{kg} / \mathrm{m}^{3}$, respectively; $\rho_{f}^{a}$ is the average density of the filler in the compacted state (analogous to the bulk density of concrete fillers) $\mathrm{kg} / \mathrm{m}^{3}$; $S / C, W / C, F / C$ are the quantitative mass relationship of appropriate composition components.

\section{Conclusions}

Thus, the algorithm used for the definition of electric resistance of a composite material using data on the specific electric resistance of the filler and matrix and the composition of composite material for research or technological purposes can be described as:

1) the separation factor of filler particles by the matrix $\eta$ is determined using data on composition and physical properties of the components of composite materials and formulae (24) and (25) or analogous formulae; (23);

2) the matrix interlayer thickness between the filler particles $\delta$ is determined by formula

3) the specific electric conductivity and specific electric resistance of composite materials as the inverse value of it are derived from formula (12), using data on the specific electric resistance of the filler $\rho_{f}$ and the matrix $\rho_{m}$, the average size of filler grains $d$ and the matrix interlayer thickness between them $\delta$;

4) for the composite material with the multilevel structure the computation is done using the following procedure; first for a finer level (for example, the micro-level represented by the cement stone and the filler), then for the next level using the value of specific electric resistance obtained as that of the specific electric resistance of the matrix for the next coarser level, in particular the mezzo-level with the sand filler, and the macro-level with the crushed stone filler.

The authors express their gratitude and sincere appreciation to Dr. Oleg Kalinin and eng.Vladimir Kasyanov for their assistance in the research work. 


\section{References}

1. A.A. Starosel'skij, Korrozija i zashhita zhelezobetonnyh konstrukcij v sooruzhenijah jelektrificirovannyh zheleznyh dorog (KhIIT, Kharkov, 1988)

2. A.N. Plugin, A.A. Plugin, Al.A. Pluhin, A.A. Dudin, Collected scientific works of Ukrainian State University of Railway Transport, 111, 245-261 (2009)

3. V.V. Palij, A.N. Pshin'ko, A.N. Plugin, A.A. Plugin, S.G. Nesterenko, A.A. Konev, Collected scientific works of Ukrainian State University of Railway Transport, 134, 235-241 (2012)

4. L.E. Vrublevskij, Vozmozhnosti ispol'zovanija jelektroprovodnogo betona (betjela) v grazhdanskom stroitel'stve (CNTI, Moscow, 1971)

5. E.K. Pushkareva, S.H. Huziy, Budivnytstvo, 9, 54-57 (2001)

6. A.N. Lopanov, E.A. Fanina, O.N. Guzeeva, ARPN Journal of Engineering and Applied Sciences, 9 (11), 2250-2253 (2014)

7. O.V. Khrystych, M.S. Lemeshev, Visnyk of Vinnytsia Politechnical Institute, 2, 18-23 (1998)

8. A.N. Lopanov, E.A. Fanina, O.N. Tomarovshhenko, Bulletin of BSTU named after V.G. Shukhov, 1, 130-133 (2017)

9. V.R. Serdyuk, M.S. Lemeshev, O.V. Khrystych, Visnyk of Vinnytsia Politechnical Institute, 2, 5-9 (1997)

10. K.K. Pushkar'ova, S.H. Huziy, Resursoekonomni materialy, konstruktsiyi, budivli ta sporudy, 5, 82-85 (2000)

11. E.K. Pushkareva, S.H. Huzyy, Naukovo-praktychni problemy modelyuvannya ta prohnozuvannya nadzvychaynykh sytuatsiy, 5, 23-29 (2002)

12. A.N. Lopanov, E.A. Fanina, O.N. Guzeeva, VESTNIK MGSU, 8, 78-87 (2016)

13. A.N. Lopanov, O.N. Guzeeva, I.V. Prushkovsky, K.V. Tikhomirova, ARPN Journal of Engineering and Applied Sciences, 9 (11), 2275-2278 (2014)

14. A.F. Bernackij, Ju.V. Tselebrovskij, V.A. Chunchin, Elektricheskie svojstva betona (Energiya, Moscow, 1980)

15. L. Brautman, R. Krok, B. Noton, Kompozitsionnyy materialy. T. 3: Primenenie kompozitsionnykh materialov v tekhnike (Mashinostroenie, Moscow, 1978)

16. A.A. Plugin, Sovershenstvovanie sostava i struktury betona s uchetom ehlektro poverhnostnyh svojstv ego sostavlyayushchih dlya povysheniya prochnosti $i$ stojkosti izdelij kolcevogo secheniya (Thesis of Cand. Tech. Sciences, Kharkov, 1994)

17. A.A. Plugin, O.A. Plugin, H.-B. Fisher, G.N. Shabanova, 1 Weimarer Gipstagung, Weimar, 435-443 (2011)

18. A.N. Plugin, Ehlektrogeterogennye vzaimodejstviya pri tverdenii cementnyh vyazhushchih (Thesis of DSc (Chem), Kiev, 1989)

19. M.P. Shaskolskaya, Kristallografiya (Vysshaya Shkola, Moscow, 1976)

20. A.E. Sheikin, Yu.V. Chekhovsky, M.I. Brusser, Struktura i svojstva cementnyh betonov (Strojizdat, Moscow, 1979)

21. I.A. Rybev, Stroitelnye materialy na osnove vyazhushchih veshchestv (Vysshaya Shkola, Moscow, 1978) 